\title{
A ASSIMILAÇÃO DOS IMIGRANTES COMO QUESTÃO NACIONAL
}

Giralda Seyferth

\begin{abstract}
“Cinqüenta anos de República irresponsável e alguns anos de descuido do Império permitiram que os núcleos de colonização estrangeira se transformassem em verdadeiros quistos raciais; ameaçadores de nossa soberania, centros de divulgação e irradiação de ideais alienígenas, soluções de continuidade do espírito nacional" (Bethlem 1939:IX).
\end{abstract}

Entre 1937 e 1945 uma parcela significativa da população brasileira sofreu interferências na vida cotidiana produzidas por uma "campanha de nacionalização" que visava ao caldeamento de todos os alienígenas em nome da unidade nacional. A categoria "alienígena" - preponderante no jargão oficial - englobava imigrantes e descendentes de imigrantes classificados como "não-assimilados", portadores de culturas incompatíveis com os princípios da brasilidade. A campanha foi concebida como "guerra" para erradicação de idéias alienígenas, com o objetivo de impor o "espírito nacional" aos patrícios que formavam "quistos étnicos" erroneamente tolerados pelo liberalismo da República Velha. Seus idealizadores criticavam, sobretudo, a política de colonização com imigrantes mantida durante a Primeira República, argumentando que a elite não corrigiu os "erros" cometidos no Império, permitindo que estrangeiros formassem núcleos isolados, quase imunes ao processo assimilador característico da formação social brasileira1.

O Exército teve papel preponderante na concepção e efetivação prática da campanha, pressupondo que os núcleos de "colonização estrangeira" constituíam "quistos" no corpo da nação². Na visão militar, uma anomalia desse tipo só podia ser eliminada através da ação cívica de todos os patriotas que pretendiam viver num Brasil uno, independente e forte.

A presença de grupos étnicos formados no curso do processo imigratório, concentrados de forma expressiva nos quatro estados mais ao sul 
do país, suscitou diversas manifestações de xenofobia no âmbito dos discursos nacionalistas mais radicais, mesmo antes de 1889. A frase em epígrafe indica o recrudescimento de uma posição nacionalista unívoca, que não faz concessões ao pluralismo étnico, assumida no contexto histórico do Estado Novo: faz parte do prefácio de um livro do tenente Hugo Bethlem, publicado em 1939. Trata-se de uma narrativa de viagem cívica pelo Vale do Itajaí, preparatória de uma intervenção direta do Exército nas instituições e na vida cotidiana em uma região marcada pela presença preponderante de descendentes de imigrantes alemães ciosos da sua identidade teuto-brasileira, considerada incompatível com o jus soli. Além disso, as denúncias sobre a atuação nazista ajudaram a construir uma imagem negativa dessa população, "cérebros envenenados" pela doutrinação praticada pelos agentes do III Reich (Bethlem 1939:139).

Isso não significa que só a população de origem alemã foi considerada alienígena: quase todos os descendentes de imigrantes, em algum grau, estavam desnacionalizados na opinião de Bethlem e outros participantes da campanha. No entanto, os indícios de maior resistência ao "abrasileiramento" foram encontrados naquelas regiões consideradas "redutos do germanismo", constituindo uma situação de risco para a integridade cultural, racial e territorial da nação.

Trata-se, pois, de um discurso nacionalista aparentemente novo, que retoma a velha retórica sobre o "perigo alemão" construída a partir de denúncias sobre as atividades pangermanistas no sul, antes da Primeira Guerra M undial. A imagem da unidade nacional ameaçada por imigrantes concentrados em regiões problemáticas, principalmente no Rio Grande do Sul e Santa Catarina, sob influência de doutrinas estrangeiras, construída no texto de Bethlem, já está presente em alguns discursos nacionalistas do Império. E para ficar com um exemplo emblemático, pode ser citada a posição de Silvio Romero que, na penúltima década do século XIX, já demonstrava sua preocupação com os mesmos "quistos étnicos", culpando a política imigratória do Império pela situação "calamitosa" das "colônias alemãs". Para Romero, o risco do separatismo só podia ser debelado através da imposição de uma política imigratória que distribuísse os brancos europeus por todo o país, de forma a promover o equilíbrio populacional, e com intervenção direta na organização comunitária dos imigrantes localizados no sul, forçando a assimilação e o caldeamento3.

A campanha de nacionalização foi implementada durante o Estado Novo (1937-1945), atingindo todos os possíveis alienígenas - tanto nas áreas coloniais (consideradas as mais enquistadas e afastadas da socie- 
dade brasileira) como nas cidades onde as organizações étnicas estavam mais visíveis. $O$ primeiro ato de nacionalização atingiu o sistema de ensino em língua estrangeira: a nova legislação obrigou as chamadas "escolas estrangeiras" a modificar seus currículos e dispensar os professores "desnacionalizados"; as que não conseguiram (ou não quiseram) cumprir a lei foram fechadas. A partir de 1939, a intervenção direta recrudesceu e a exigência de "abrasileiramento" através da assimilação e caldeamento tornou-se impositiva - criando entraves para toda a organização comunitária étnica de diversos grupos imigrados. Assim, progressivamente, desapareceram as publicações em língua estrangeira, principalmente a imprensa étnica, e algumas sociedades recreativas, esportivas e culturais que não aceitaram as mudanças; foi proibido o uso de línguas estrangeiras em público, inclusive nas atividades religiosas; e a ação direta do Exército impôs normas de civismo, o uso da língua portuguesa e o recrutamento dos jovens para o serviço militar num contexto genuinamente brasileiro. A participação do Brasil na guerra, a partir de 1942, acirrou as animosidades pois a ação nacionalizadora se intensificou junto aos imigrantes (e descendentes) alemães, italianos e japoneses - transformados, também, em potenciais "inimigos da pátria".

Os excessos cometidos na repressão aos "ideais alienígenas" são reconhecidos por alguns participantes da campanha; mas, ao mesmo tempo, são debitados à repercussão dos acontecimentos internacionais 4 . Prisões arbitrárias, policiamento ostensivo, humilhações públicas como castigo pelo uso de língua estrangeira, cerceamento de atividades produtivas, associações esportivas requisitadas para uso militar etc. marcaram o cotidiano tenso de algumas regiões onde a maioria da população se enquadrava na categoria dos alienígenas.

Este artigo focaliza o discurso nacional ista produzido por militares que participaram da campanha de nacionalização do Vale do Itajaí e definiram os núcleos coloniais fundados por alemães, poloneses e italianos nos três estados do sul como modelos de enquistamento étnico, contaminados pelos ideais do jus sanguinis, ameaçando a unidade da pátria. Objetiva mostrar que prevaleceu uma concepção de Estado-nação que nega legitimidade às etnicidades, conforme parâmetros característicos da ideologia nacionalista brasileira gestada desde o século XIX, e que privilegiou a assimilação e o caldeamento racial como base da formação nacional. Destaca a hegemonia de uma visão militar - e o próprio uso do termo "campanha" é, nesse sentido, significativo - na qual os alienígenas (inclusive os nascidos no Brasil) são personagens que precisam ser "conquistados" através da imposição do civismo, num cenário conflituo- 
so definido como "estado de guerra", onde ressurge o velho confronto entre jus soli e jus sanguinis.

\section{A "Campanha" e o Vale do Itajaí}

Os trabalhos de Hugo Bethlem (1939), Rui Alencar Nogueira (1947) e Theobaldo Costa J amundá (1968) - jovens oficiais do Exército em 1939 - representam bem o nacionalismo dos militares responsáveis pela execução da campanha de nacionalização no Rio Grande do Sul, Santa Catarina e Paraná. Nogueira e Bethlem falam dos imperativos do abrasileiramento e expõem seu estranhamento diante de uma realidade diversa do Brasil tradicional, numa condenação radical ao que consideram ser um comportamento antipatriótico, sobretudo por parte dos brasileiros de origem alemã. $\mathrm{O}$ texto de J amundá tenta resgatar, de forma laudatória, a ação do interventor em Santa Catarina durante o Estado N ovo - Nereu Ramos - que cumpriu à risca as determinações da campanha, baixando decretos que normatizaram a intervenção nas escolas, associações e outras instituições demarcadoras de pertencimento étnico e cerceando as aspirações políticas de al gumas lideranças expressivas das regiões "desnacionalizadas". N ele o autor expõe sua opinião sobre a campanha, que ajudou a implantar acantonado num dos municípios do Vale do Itajaí. N os três autores, o Vale do Itajaí (contíguo à área de influência de outro município surgido no contexto da imigração alemã - J oinville, no noroeste do estado) aparece como paradigma da influência estrangeira no país por sua vinculação à colonização alemã.

A escolha de três autores referidos ao Vale do Itajaí não é arbitrária: em 1937 essa região possuía o maior número de el eitores do estado, seu parque industrial se desenvolvia rapidamente e sua população era majoritariamente composta de descendentes de imigrantes alemães, italianos e poloneses, portadores de identidades étnicas fundamentadas em práticas culturais específicas e no pertencimento primordial às nacionalidades de origem, com base no direito de sangue. O fluxo imigratório praticamente havia terminado em meados da década de 30 , mas a região recebeu imigrantes, de forma continuada, desde a fundação da principal colônia em 1850 - uma iniciativa particular do alemão Hermann Blumenau 5 .

A maior parte dos imigrantes que participaram do povoamento da região veio de diferentes estados alemães; em meados da década de 1870, chegaram os primeiros italianos, assentados em áreas ainda não ocupadas pelos alemães, formando, em alguns casos, núcleos etnicamente 
homogêneos. Além dos alemães e italianos, o processo de colonização oficial ou privado - instaurado pelo Estado trouxe imigrantes poloneses, suecos, húngaros, austríacos, russos, franceses e irlandeses6; mas existem poucos indícios de assentamentos de colonos brasileiros. A presença insignificante de nacionais, assim, preocupou uma parte da elite nacionalista desde o século XIX, embora a política de colonização fosse assunto exclusivo do poder público - mesmo no caso das companhias particulares de colonização. Coube, pois, ao Estado brasileiro ditar as normas de colonização (através de uma legislação específica) e às províncias de implementá-las. Os brasileiros das classes dominadas - potenciais candidatos a colonos - ficaram à margem do sistema, duplamente desqualificados como trabal hadores despreparados para as atividades produtivas "modernas" e como elementos de raça supostamente inferior?.

O discurso racial que, em grande parte, dominou a discussão da política imigratória não vai ser invocado em termos críticos quando os nacionalizadores de 1937 e 1939 falam dos "erros" da velha República liberal. Para alguns deles, como Nogueira (1947), o racismo é prerrogativa dos alienígenas que não quiseram ser caldeados dentro dos princípios da formação brasileira. Nesse caso, o erro maior estaria na ausência de imposição de um processo assimilador desde o início da República - período em que o fluxo imigratório se intensificou. Enfim, na década de 30, o Vale do Itajaí aparece como um lugar de costumes estranhos, cheio de brasileiros (segundo o princípio do jus soli) desnacionalizados, contaminados por ideais de nação que solapavam a brasilidade, um lugar de "desagregação do espírito nacional". Sendo uma região com predominância de descendentes de colonos alemães, as atividades nazistas, bem como o aumento do fluxo imigratório proveniente da Alemanha na década de 20, são fatos que serviram de argumento para a condenação veemente do pluralismo cultural no âmbito de um enunciado assimilacionista mais radical.

Conforme dados numéricos constantes no estudo de Carneiro (1950), a imigração alemã para o Brasil cresceu significativamente nos primeiros anos da década de 20, para depois decrescer até tornar-se insignificante na década de 30; sua drástica redução não se deve, propriamente, à instituição do regime de cotas, a partir de 19348. Esse contingente não se dirigiu com exclusividade para o sul, e muito menos para o Vale do Itajaí; mas os que ali se estabeleceram receberam da população teuto-brasileira uma denominação identitária diversa - Neudeutscher (alemães novos), evidenciando estilos de vida e concepções de mundo diferentes no interior da comunidade étnica (mas sem criar clivagens irredutíveis). De qualquer modo, no enunciado assimilacionista da campanha, a manutenção 
do fluxo imigratório aparece como causa da desnacionalização pelo que representa em termos da manutenção da língua e da cultura alemãs, juntamente com a atividade de propaganda dos agentes nazistas.

A retórica aparentemente mais antigermânica, acirrada pelas denúncias sobre as atividades do partido nazista, não significa que os demais grupos de origem européia fossem menos visados: estavam todos incluídos na categoria genérica de "cidadãos não-assimilados", portanto, não legitimados como brasileiros.

A ação nacionalizadora nos estados do Rio Grande do Sul, Santa Catarina e Paraná foi planejada pelo general J osé M eira de Vasconcellos, no comando da 5a Região M ilitar e da 5a Divisão de Infantaria, com sede em Curitiba, e conduzida por seu substituto no comando a partir de 1939 - o general Manuel Rebello. A motivação do general Vasconcellos é interpretada como a reação de "um general brasileiro, nem mais, nem menos" diante de tantos "brasileiros divorciados da unidade cultural da nação" (J amundá 1968:13). Esta frase de efeito tem um significado preciso: o Exército assumiu o papel de nacionalizador em 1939, quando já estava em curso a intervenção nas escolas com ensino em língua estrangeira, relativamente numerosas nos três estados do sul ${ }^{9}$, para garantir a coesão de todos os brasileiros na totalidade representada pelo Estado-nação.

A tarefa da nacionalização assumida como "campanha" militar uma guerra contra idéias alienígenas - tem a ver com a expansão e o fortalecimento político do Exército durante o Estado Novo. Conforme análise de Edmundo Campos Coelho, em 1937 a liderança do Exército tornou-se avalista do Estado N ovo - que considera um "regime militar em sua essência" (Coelho 1976:97). A maioria dos estudiosos desse período histórico não define o Estado Novo como uma ditadura militar, mas destaca o papel do Exército nos processos decisórios ${ }^{10}$. $\mathrm{Na}$ ação intervencionista que atingiu a população descendente de imigrantes, o Exército assumiu a tarefa de construtor da nacionalidade - supondo que a elite republicana antes de 1937 havia sido descuidada quanto aos valores morais constitutivos da nação. Nacionalizar, portanto, é tarefa de educação moral e cívica - um pressuposto dos doutrinadores que estabeleceram as premissas ideológicas da ação do Estado. Esse processo educativo, contudo, não foi pensado apenas para enquadrar os alienígenas ao postulado de uma nação pensada como totalidade; também o trabalhador brasileiro devia passar por um processo educacional de inculcação de valores patrióticos ${ }^{11}$. De qualquer modo, a valorização dos trabalhadores brasileiros coincidiu com a condenação da política imigratória liberal, que permitiu a fixação intensiva de estrangeiros no sul, descuidando do 
equilíbrio regional. Essa condenação lembra o alerta de Silvio Romero, em 1905, sobre os desequilíbrios regionais, mas a solução proposta por ele não servia aos interesses do Estado em 1939. Longe de propor uma política de imigração que contemplasse todo o território brasileiro, os nacionalistas do Estado N ovo consideraram o Nordeste uma espécie de reservatório de brasilidade, justamente porque ficou fora do processo imigratório12. Assim, o Brasil mais tradicional possuía o elemento humano mais apropriado para nacionalizar o sul. Torna-se, então, significativo que dois dos autores mencionados - J amundá e Nogueira - sejam nordestinos; e que muitos sol dados que seguiram para Blumenau com o 32으 Batal hão de Caçadores, em 1939, tenham sido recrutados no nordeste.

Nessa perspectiva, o elemento humano representativo da formação nacional mais legítima tinha a missão de incorporar os imigrantes e seus descendentes ao amálgama imaginado no mito das três raças formadoras da nação (o povo brasileiro como resultado da miscigenação de brancos, negros e indígenas). O pressuposto de unidade contido no mito é invocado através de uma frase de Getúlio Vargas, citada por Bethlem (1939:160161) de forma mais textual: “Um país, acentuava há dias o Presidente Getúlio Vargas, não é apenas um conglomerado de indivíduos dentro de um trecho de território, mas, principalmente, a unidade de raça, a unidade de língua, a unidade do pensamento nacional."

Isso significa que o jus soli, por si mesmo, não era critério absoluto ou suficiente de cidadania, uma vez que para ser cidadão era preciso ser também um nacional: os alienígenas podiam nascer brasileiros, mas não pertenciam à nação brasileira. A invocação do jus soli, presente no discurso feito por Vargas em Blumenau em 10 de março de 1940, serviu para enquadrar filhos e netos de imigrantes como brasileiros, porém desprovidos de brasilidade; uma brasilidade que só podia ser atingida pela educação. E a tarefa de educar também era uma tarefa do Exército nacional - ali responsável pela nacionalização. A ele cabia inculcar no elemento de procedência estranha o "sentido nacional"13.

Os textos de Bethlem, Nogueira e J amundá refletem diferentes modos de confrontar a realidade vivenciada durante a campanha, a partir dessa imagem do Estado-nação.

O livro de Bethlem descreve como "jornada cívica” uma viagem de Curitiba ao Vale do Itajaí (passando por J oinville), da qual participaram várias autoridades militares e civis, entre elas o general M eira de Vasconcellos e o interventor em Santa Catarina, Nereu Ramos. Essa viagem precedeu a intervenção militar no curso da campanha, até 1939 restrita às "escolas estrangeiras". Bethlem, numa retórica de conteúdo radical- 
mente patriótico, defende a ação militar nas regiões desnacionalizadas em nome da necessidade do "caldeamento".

Nogueira escreve sobre sua experiência como tenente integrante do 32o Batalhão de Caçadores, na fase de sua organização na cidade de Blumenau. Mais do que um livro que tenta justificar a campanha, o texto expõe o estranhamento de um brasileiro que se identifica como autêntico em confronto com uma sociedade e uma cultura diferentes da "realidade nacional", desqualificada como estranha, alienígena.

O livro de J amundá não é uma biografia de Nereu Ramos, como o título parece sugerir; faz a defesa do interventor do Estado Novo em Santa Catarina como um "nacionalizador responsável" caluniado por detratores interessados no el eitorado alienígena. É um texto mais distanciado dos acontecimentos, publicado como edição do autor em 1968, que aponta para os problemas de natureza política gerados pela ação dos nacionalizadores mais radicais.

\section{Os "quistos raciais" e o "espírito nacional"}

Sob o impacto de uma viagem de natureza cívica a uma região "desligada da harmonia nacional", segundo seus termos, Bethlem usa e abusa de uma terminologia própria da patologia médica e, de forma mais direta, concebe a campanha como uma "guerra" - "cruzada empolgante para todos os patriotas" - na qual o germanismo não era a única frente a vencer. Nessa referência associada aos ideais de pertencimento étnico da população de origem alemã, o inimigo mais óbvio era uma ideologia - o germanismo - naquele momento atualizada pela influência do nazismo e de seus agentes. A campanha é quase sempre referenciada como uma grande cruzada antinazista mas, na realidade, pretendia atingir a organização comunitária étnica de todos os imigrados, associando sua persistência a princípios nacionalistas artificialmente incorporados por agentes estranhos. $\mathrm{O}$ "estado de guerra" a que se refere Bethlem, em diferentes partes do seu texto, era também contra o que chamou de "solerte e profunda infiltração polaca e a fraca mas decisiva organização italiana" (Bethlem 1939:13).

Num continuum de desnacionalização, os alemães eram os mais alienígenas, os italianos estavam mais próximos dos brasileiros, e os poloneses ocupavam um espaço intermediário - mas nenhum deles podia ostentar a identidade inequívoca de brasileiro em sua concepção cultural e racial. 
Ao conceber a campanha como guerra, Bethlem não estava usando apenas uma figura de retórica: na primeira parte do livro indica que houve uma avaliação da situação das regiões coloniais do sul, do ponto de vista da desnacionalização, mostrando-se otimista por não ser necessária uma intervenção armada. No seu modo de ver a "situação calamitosa", julgava possível transformar potenciais inimigos ("infestados, infelizmente, pelo vírus da desnacionalização") em irmãos, através da imposição da brasilidade. "Guerra" de ideais incompatíveis - nacionalismo contra etnicidade - como expressão da "tremenda preocupação do grande futuro do Brasil, minado por quistos exóticos há 50 anos de República se formando, com inconcebíveis pretensões a minorias raciais [...]" (Bethlem 1939:14).

Assim, os grupos étnicos e suas culturas são definidos como quistos (ora raciais, ora exóticos, ora alienígenas) e as etnicidades, expressadas por termos como germanismo, polonidade, italianidade etc., são vírus que atingiram o corpo da nação, ameaçando sua integridade. Vírus que impõem vinculações com "pátrias artificiais" (os países de origem dos imigrantes) que afetaram a mente da nação e a sua própria razão de ser. Só podiam ser vencidos, erradicados, se fossem atacados os grandes baluartes antinacionais dos alienígenas: a escola, o lar e a Igreja.

Examinando os discursos étnicos definidores das etnicidades dos grupos de origem européia (citados freqüentemente por Bethlem) na década de 30, percebe-se que estão baseados em critérios simbólicos primordialistas, que apontam para pertencimentos nacionais definidos pelo jus sanguinis. Nesses discursos, escola, Iar, Igreja e associações recreativas/culturais aparecem como instituições fundamentais para a manutenção das identidades étnicas, já que sua ação permite a continuidade do aprendizado da língua e dos costumes "de origem". Isto é, na construção das identidades étnicas", a língua, a cultura e a origem (que supõe laços de sangue com uma nação específica) aparecem como símbolos de pertencimento que Max Weber assinalou como básicos dos sentimentos étnicos e nacionais (cf. Weber 1992:cap. IV). No entanto, o que Bethlem e os outros nacionalizadores encontraram não se reduz a comunidades imaginadas ou tradições inventadas ${ }^{14}$ características das formulações das etnicidades e dos nacionalismos: as diversas ideologias étnicas tinham uma contrapartida na realidade, pois o processo histórico de imigração e colonização produziu sociedades diferentes da brasileira, com instituições etnicamente definidas, e onde os idiomas de origem se tornaram idiomas do cotidiano. M ais do que as idéias alienígenas e as identidades étnicas definidas e veiculadas em jornais, escolas etc., os 
cenários cultural e social das colônias, sua vida cotidiana, comprometiam e afrontavam a concepção de unidade nacional. Ali "perdia-se a sensação de Brasil" - sentimento presente nos três autores em questão.

Se, por um lado, Bethlem parece condenar com maior veemência aqueles que chama de "agentes mercenários" pela falta de brasilidade e sentimentos cívicos nos "quistos raciais", por outro, os elementos da ação nacionalizadora propostos por ele atingem, precisamente, as instituições: obrigatoriedade do ensino em português; fechamento das associações, escolas e jornais; introdução do escotismo para impor o civismo e chegar, através dos jovens, até ao lar; imposição a padres, pastores e fiéis do uso da língua portuguesa nos serviços religiosos; recrutamento para serviço militar longe das colônias; organização de festas cívicas com participação obrigatória.

"Agentes mercenários" é uma categoria que engloba todas as possíveis lideranças étnicas - nazistas, padres, jornalistas, professores, entre outros, nascidos ou não no país - como se constata na opinião que emite sobre os padres poloneses, considerados responsáveis pelo "espírito de polonidade" presente nas colônias do Paraná.

“A estes [padres] ajuda, de uma forma impressionante, pela inflexibilidade cega, a mulher de origem polaca, que, conservada feudalmente nos princípios drásticos da organização polaca, se mantém ignorante e crente e, só falando polaco, é quem conduz, através da educação no lar, o espírito de polonidade por todas as gerações.

A igreja polaca nas colônias as domina, e elas, clericais e arraigadas, mantêm bem firme esta arma fatídica, que suas inconsciências invencíveis manejam, semeando o terreno das futuras dissensões raciais. Só o padre as poderá vencer se este for por nós vencido" (Bethlem 1939:25-26).

Duas questões estão implícitas nesse texto. Em primeiro lugar, mostra que a presença nazista, usada como argumento mais freqüente para o desencadeamento de uma campanha coercitiva de "abrasileiramento", não foi nem a única nem a principal razão da intervenção militar nas colônias do sul ${ }^{15}$. M esmo nas referências mais diretas relacionadas às colônias alemãs, ou nos comentários acerca da negligência das "autoridades passadas" (da República Velha) em assegurar a assimilação dos imigrantes, considera que os "agentes mercenários" que começaram a "invadir o Brasil alojando-se nas colônias" encontraram uma situação propícia para reforçar o civismo baseado no jus sanguinis. Trata-se, então, de uma guerra de mentalidades onde o princípio do jus sanguinis, "estranho" e 
"absurdo" para os brasileiros, deve ser derrotado, substituído, por uma compreensão da "verdadeira pátria" - ponto de partida para o processo de caldeamento. Em segundo lugar, a avaliação do papel das mulheres polonesas na manutenção dos sentimentos de polonidade, numa forma sutil ancorada ao tema da desnacionalização, revela o preconceito sobre os "colonos estrangeiros" presente, também, em outras partes do livro. Não é apenas a intolerância de um patriota com os brasileiros natos que "se consideram estrangeiros" e nada conhecem da sua "verdadeira pátria", ou que demonstra seu espanto diante das estatísticas sobre o emprego usual da língua alemã16. A desqualificação dos colonos se faz, igualmente, por critérios que nada têm a ver com as etnicidades: no texto citado, a mulher polonesa é ignorante, feudal, inconsciente. Em outro momento, joga sua retórica nacional ista contra um dos meios de transporte usados pelos colonos, após exaustiva descrição do mau estado das estradas do Paraná e Santa Catarina: “A carroça polaca, brutalmente pesada, é que é a verdadeira responsável pelo estrago permanente destas estradas de piso de terra e com pouca ou nenhuma conservação" (Bethlem 1939:118).

Descreve a "carroça polaca" detalhadamente, com adjetivos desabonadores - "pitoresca e suja", "pesada e baixa", "pachorrenta e calma", "um mínimo de carga devido a seu peso", "obstáculo perigoso" (porque atrapalha o tráfego de automóveis e seus condutores "não se abalam por nada deste mundo") - concluindo, "no Paraná elas existem aos milhares, invadem mesmo o maior centro do Estado - Curitiba - e em plena rua, num contraste chocante, passam na sua fleugma extraordinária, indiferente ao tempo [...]" (Bethlem 1939:120).

A natureza metafórica dessa imagem da "carroça polaca" fica mais evidente porque o autor indica causas bem mais óbvias da deterioração das estradas (como a falta de conservação, tráfego de caminhões carregados com madeira etc.). A carroça carrega, na verdade, os estigmas da condição de colono, representações bastante comuns sobre o campesinato e o meio rural onde não faltam indicativos de atraso e arcaísmo, também presentes em al guns estudos acadêmicos sobre a aculturação dos imigrantes ${ }^{17}$.

A lém disso, o estigma é reforçado pelo uso da categoria polaco/polaca, que tem um conteúdo identitário de atribuição pelos outros, não reconhecido no contexto da polonidade. Bethlem fala exclusivamente de polacos, não de poloneses, e a organização étnica do grupo polonês é classificada como "chaga" mantida pelas sociedades culturais e educacionais repletas de "traidores da causa nacional". 
“Conduzida com tenacidade, ela [a campanha de nacionalização] começou a trazer um conhecimento mais profundo sobre a extensão da chaga e tristemente reconheceram que era imensa, que a penetração fora longe, que era grande o número de brasileiros de origem polaca, que embora conscientes de suas traições, se deixaram subornar e se ofereceram pela causa da polonidade contra a causa nacional" (Bethlem 1939:58).

Como se vê, nazismo à parte, não existem diferenças na maneira de condenar as etnicidades de quaisquer um dos grupos de origem européia que participaram da colonização do sul do Brasil. No caso dos alemães, os “agentes mercenários" são, invariavelmente, os nazistas, entre os poloneses são os padres e, em todos os casos, as mulheres e os professores das "escolas estrangeiras" - todos imbuídos da noção de "pátria artificial", mentirosa porque baseada no jus sanguinis. Do colo da mãe até a escola (e a igreja) a criança é criada para ter "a sensação exótica, pouco compreensível, mas nítida, de amar uma pátria que não vê, não conhece, não sabe como é [...]. A ação violenta, somente a revolta, e a imposição brutal de deveres para com sua verdadeira pátria, a encontra reacionária e perigosa" (Bethlem 1939:43).

A qui, a justificativa para a ação impositiva da brasilidade é a germanização de crianças que têm a convicção de serem alemãs. O tema reaparece em várias partes do texto, ressaltando a figura materna e o lar como elementos fundamentais de socialização étnica. No contexto do combate aos ideais alienígenas, a campanha precisava chegar até o “joeIho da mamãe" , colorir as crianças de verde-amarelo através do escotismo para atingir os pais (cf. Bethlem 1939:188).

Assim, as medidas propostas demonstram a existência de uma percepção clara das formas de transmissão dos valores étnicos, o que explica o radicalismo das práticas de nacionalização. A representação da brasilidade não admitia sequer resíduos de outras tradições culturais - daí a proposta de interferir no lar alienígena.

A compreensão da etnicidade passa pelo entendimento do componente afetivo da identidade étnica - símbolos e valores transmitidos nos círculos mais íntimos de convivência: o lar, as relações de parentesco e a amizade. De acordo com Epstein (1978), etnicidade envolve certo grau de emoção e o comportamento étnico não pode ser governado apenas por um cálculo racional. Talcott Parsons, focalizando algumas características primárias dos grupos étnicos nos Estados Unidos, mostra que o papel da mãe na transmissão dos valores étnicos é reafirmado em quase todos os grupos - ela aparece como "guardiã simbólica da identidade étnica" 
(Parsons 1975:65). Nas manifestações de pertencimento étnico/nacional entre descendentes de alemães, italianos e poloneses, observáveis, por exemplo, na imprensa e em textos escolares e comemorativos, os nacionalizadores de 1939 encontraram referências à importância da família na preservação da língua materna e de outros elementos culturais indicativos de limites intergrupais.

Chegar até o "joelho da mamãe" - portanto, atingir o âmago da socialização étnica - sem uso da "força bruta", era para Bethlem uma questão de educação cívica: a campanha precisava mudar a mentalidade dos filhos para impor no lar o espírito de brasilidade.

Parte do texto, então, contém a descrição de diversas festas cívicas organizadas no curso da viagem, e transcrição de discursos de Nereu Ramos e do general Vasconcellos (o que explica o subtítulo “J ornadas de Civismo"), al ém do registro indignado da "indiferença" com que foram recebidos. A nacionalização, nesse contexto cívico, é definida como "obra de renascimento", de "reconstrução", de "brasilidade" - temas reforçados na transcrição que faz do discurso pronunciado pelo interventor catarinense em Blumenau.

“Na obra de brasilidade que se está incentivando [...] não vai hostilidade a qualquer povo ou a qualquer raça. Bem ao revés, encontra paradigma e exemplo na experiência e nos ensinamentos das nações que mais hão contribuído para o desenvolvimento material do nosso país. A ssim como, através de seus filhos, e até além de suas fronteiras, procuram elas conservar e desenvolver o amor das suas tradições e da sua língua, dever nosso é impedir que os que aqui nasceram e aqui vivem, ao invés da língua e das tradições do Brasil, se apeguem e se aferrem às de outros povos ou de outras nações.

Nós respeitamos os estrangeiros nos direitos que Ihes asseguramos, por isso que são valiosos elementos de colaboração para o nosso progresso. Mas nem porque os recebemos com a doçura do nosso temperamento; nem porque os acol hemos com a hospitalidade que é traço inconfundível do nosso caráter, abrimos mão do direito que nos é fundamental como nação soberana, de orientar e dirigir a formação moral e cívica dos que nasceram no Brasil e brasileiros são.

\section{[...]}

A hora é de renascimento. A Constituição de 10 de N ovembro é alvorada de um Brasil mais forte e mais unido. A condição primeira dessa suprema realização nacional é que dentro dele, em nenhuma de suas regiões, prevaleçam ou predominem por incúria ou descaso de governos ou pela resistência de 
elementos alienígenas, língua que não seja a nossa, tradições outras que as do nosso próprio passado, glórias que não as dos nossos próprios fastos" (Bethlem 1939:161-163).

A ênfase no civismo só não obscurece a questão central que surge nesse discurso, presente em todo o livro: a unidade nacional exigia a eliminação das línguas e tradições culturais alienígenas conservadas por indivíduos nascidos no país, portanto, "brasileiros".

A língua portuguesa aparece como critério fundamental da nacionalidade, justificando a nacionalização do ensino e o fechamento das escolas étnicas. A impossibilidade de substituir todas as escolas (com o conseqüente risco para o ensino fundamental nas áreas de colonização estrangeira) pode até ser vista como "grave inconveniente", mas era "preferível que se fizesse, como brilhantemente sintetizou o General em seu pensar candente: 'Antes criarmos ignorantes, que criarmos traidores!..'” (Bethlem 1939:66).

"Traidores da pátria", ou inimigos, podem ser quase todos: o padre polonês “inflexível”, "teimoso”, “arrogante”; a mãe que ensina uma língua estrangeira a seus filhos; aqueles que divulgam noções artificiais de nacionalidade, atropelando a noção de jus soli (aí incluídos os nazistas); os "cérebros envenenados" 18 que não aceitavam a pujança da doutrinação patriótica; enfim, todos aqueles contaminados pelo vírus da desnacionalização.

A idéia de traição evoca um outro fantasma do nacionalismo: a ameaça de secessão não constitui uma novidade no que diz respeito à definição do Estado-nação; muito antes de 1939, nacionalistas brasileiros temiam o desmembramento da região sul, considerada excessivamente germanizada19. Bethlem não remete ao nazismo e aos avanços de Hitler no território europeu - apesar de ter sido um dos argumentos mais fortes a favor da intervenção militar no sul. A imagem de secessão é delineada sobre a diversidade étnica produzida pela imigração (que rompe a unidade) e a guerra civil espanhola20 aparece como exemplo do que poderia acontecer no Brasil: irmãos (os descendentes de imigrantes) se transformando em inimigos, conduzidos por interesses de potências estrangeiras, comprometendo uma unidade "conquistada em mais de quatrocentos anos de lutas e sofrimentos inenarráveis" (conforme palavras do general Vasconcellos, transcritas em Bethlem 1939:192).

Nesse sentido, a "mentalidade irridente" (Bethlem 1939:226) precisava ser erradicada e a campanha de nacionalização conduzida como “problema nacional” pelas Forças Armadas. 
A retórica patriótica é bem mais enfática quando se trata de discutir o tema do caldeamento (a palavra miscigenação está ausente no livro) a fórmula ideal, mitificada, de assimilação dos imigrantes. $O$ discurso proferido pelo general Vasconcellos em Blumenau (na mesma solenidade cívica em que discursou Nereu Ramos) atribui ao "caldeamento", "às transfusões de sangue" características do tipo racial deste lado do Atlântico os sentimentos de fraternidade próprios da "estrutura nacional". E conclui, numa generalização para o continente americano,

“A o lado da bondade inata, da tolerância, muitas vezes até da humildade, há na alma destes povos, o braseiro da altivez sob essa aparência de que se não suspeita. Há dentro deles a pira sagrada que acende a coivara do patriotismo que ilumina e aquece, que é clarão, que é incêndio açoitado pelo minuano quente do civismo, é pororoca, é a alma cabocla na defesa do solo a não medir sofrimentos em defesa do que é seu" (Bethlem 1939:175).

O civismo excessivo dessa passagem é exemplar, e nele a pororoca do extremo norte e o minuano do extremo sul servem de fronteiras simbólicas do território nacional - o caboclo miscigenado como elemento de união, representativo da "alma nacional". No entanto, o caboclo genérico assim definido não aparece como instrumento da nacional ização no plano militar. Para Bethlem, o 32o Batal hão de Caçadores - na época em que o livro foi escrito ainda em fase de organização para se deslocar a Blumenau, em abril de 1939 - iniciaria "o grande caldeamento" dos habitantes do Vale do Itajaí. Mas recomenda que os corpos de tropa sejam constituídos, preferencialmente, por brancos.

“[...] mandar, como preconizam alguns, contingentes de tropas do norte, legítimos indígenas, para as unidades daquela região, a fim de se proceder o caldeamento, é pior ainda. A separação se faria incontinente, separação odiosa, motivada por absoluta diferença de hábitos, costumes e mentalidades e em que os elementos nortistas não ficariam em maioria, e humilhados ou fortes, dariam expansão por causas diversas, a violências e dissensões [...].

É indispensável que [...] venham contingentes de outros recantos, de preferência e até mesmo se possível, apenas constituídos inicialmente de homens brancos.

[...]

É necessário que a escolha destes homens se faça de uma forma tal que não se estabeleça um contraste chocante com os originários da região, pela ques- 
tão dos hábitos sociais, apresentação, capacidade intelectual, etc. [...]. Não é com contingentes escolhidos à vontade só pelo fato de serem de outras regiões, que se resolverá o problema, mas principalmente com homens que no dizer preciso de Bilac, 'têm o hábito do pente, escova e sabão'" (Bethlem 1939:37-39).

Como pode ser visto, nessa longa transcrição há um pressuposto de civilização e progresso implícito na desqualificação do brasileiro comum: trata-se de abrasileirar uma população não só alienígena em pensamento e cultura, mas também escolarizada, vivendo em região de grande progresso econômico. Portanto, nacionalizar não era tarefa para qualquer um: "esta tropa será o mais selecionada possível, quanto ao físico, tipo racial, condição moral, preparo militar, saúde e apresentação” (Bethlem 1939:38).

O progresso das colônias é tema recorrente e cidades como Blumenau e J oinville recebem uma descrição positiva sempre que está em pauta seu desenvolvimento agrícola, industrial e comercial. Da mesma forma, sobram elogios para a "vida intelectual e cultural destacada" - fatores que tornam ainda mais urgente sua completa incorporação à unidade nacional (Bethlem 1939:151-152).

Diante desse quadro - em que a noção de progresso aparece como valor maior - a reeducação de "milhares de patrícios transviados da consciência nacional" é pensada como tarefa própria para pessoas educadas, oriundas do meio urbano. A referência racial mostra que, apesar do discurso nacionalista sobre a figura do brasileiro miscigenado, síntese das três raças formadoras, não estavam superadas as crenças na inferioridade racial e social do brasileiro comum. O texto de Bethlem joga com a possibilidade de reação racista dos descendentes de imigrantes caso as desigualdades fossem muito evidentes. Mas usa termos que refletem seu preconceito, e que não se limitam a destacar diferenças sociais - como a insistência em falar da aparência, tipo físico, além dos hábitos de higiene.

Esse cuidado seletivo se coaduna com o objetivo fundamental da intervenção militar - caldeamento e assimilação em curto período de tempo (que o envio de tropas inadequadas poderia comprometer). As observações feitas têm a ver com o treinamento, em Vassouras, dos soldados e oficiais que iriam formar o 32o Batalhão de Caçadores. Procurou influenciar, assim, a composição do corpo de tropa destinado a nacionalizar o Vale do Itajaí. Além disso, as observações sobre o progresso da região devem ser tomadas sob o prisma do nacionalismo econômico do Estado N ovo. A final, tratava-se de uma região com considerável influên- 
cia alemã, e os industriais e a população urbana, em geral, eram considerados, no mínimo, simpatizantes do nazismo.

$\mathrm{Na}$ verdade, todos os argumentos de Bethlem procuraram enfatizar o papel do Exército no processo de consolidação do Estado-nação - a instituição militar como responsável pelos interesses nacionais. Nesse sentido, apresenta o Exército como formador da "ossatura nacional", moralmente investido da tarefa de promover a unidade - tarefa facilitada pelo regime político instituído em 1937. "A bolido o voto, quebrada a politicagem imoral do município, pôde-se com facilidade enfrentar sem entraves dos próprios brasileiros, este problema capital: reeducação destes milhares de patrícios transviados da consciência nacional" (Bethlem 1939:78-79).

O Exército aparece, então, como mentor da solidariedade nacional, encarregado de divulgar os valores morais da nação, suas virtudes cívicas, de impor a consciência da nacionalidade, modificando a mentalidade de patrícios que não são patriotas, mas "quistos raciais" contaminando o espírito da brasilidade.

\section{Imperialismo alemão e esquisitice urbana}

O livro de Rui Alencar Nogueira resultou da passagem do autor por Blumenau como 2o tenente do 32。 Batalhão de Caçadores - onde ficou durante dois anos sob o comando do major Nilo Augusto Guerreiro Lima. Participou, portanto, da fase de implantação e organização da tropa em Blumenau - cidade que define como principal foco da "propaganda de desagregação" em Santa Catarina. Mais do que um libelo a favor da campanha, o texto reflete, sobretudo, o estranhamento de um nacional legitimado pela condição de nordestino em face de uma sociedade e cultura diferentes.

O Vale do Itajaí recebeu imigrantes de diversas procedências, mas a predominância dos alemães e da sua cultura fez com que o autor se fixasse nessa etnia como a principal ameaça aos "interesses sagrados da pátria" (Nogueira 1947:18). Se apega à idéia de nação própria do nacional ismo "tribal" a que se refere Hobsbawm (1991) e que, conforme também M auss (1969), inclui a crença na raça, na língua e na civilização únicas como fundamento da unidade do Estado-nação. Assim, considera a assimilação dos imigrantes, seu caldeamento (racial), a principal "questão nacional" a ser enfrentada no contexto das colônias "estrangeiras" do sul do país. 
De modo diverso de Bethlem, responsabiliza os imigrantes e suas lideranças pela situação de "enquistamento" étnico e traça um perfil negativo do fundador da principal colônia do Vale do Itajaí - Hermann Blumenau.

Segundo Nogueira, desde a implantação da primeira colônia no Rio Grande do Sul, em 1824, os alemães procuraram, deliberadamente, o isolamento como estratégia para manter seus costumes e raça. Para demonstrar seu ponto de vista sobre a região e sua história, usa argumentos que apagaram o fato de o Estado ter exercido o controle sobre os assentamentos de imigrantes, através de uma legislação geral que orientou os governos provinciais nas suas políticas de colonização.

A colonização alemã é, então, visualizada como um ato imperialista e as colônias classificadas como "de exploração". Ao mencionar a fundação de São Leopoldo - a primeira "colônia alemã" - por exemplo, afirma: "Conseguida a primeira etapa e após haverem fundado os alemães as primeiras colônias riograndenses, trataram de ampliar os tentáculos" (Nogueira 1947:17).

A representação contida na palavra tentáculos é clara: considera a colonização alemã uma forma ilegítima de conquista territorial, reportando a um dos grandes temas do nacionalismo (militar ou não) - o território nacional e sua unidade. Nesse caso, os imigrantes são acusados de ocupar a melhor parte do sul do país - terras férteis como o Vale do Itajaí e outras regiões importantes - numa clara referência à potencialidade econômica da exploração agrícola e industrial. Os governos anteriores ao Estado Novo, por sua vez, são acusados de conceder “vastos latifúndios" aos colonos, sem proceder a uma avaliação das "conseqüências funestas" para a unidade territorial.

A o atribuir aos imigrantes de 1824 a opção deliberada pela região sul, "mais indicada para proliferação da colônia que tinham em mira" (N ogueira 1947:16), ao considerar um lote de 75 hectares um "Iatifúndio", ao ignorar o sistema de aliciamento utilizado pelo governo imperial para atrair imigrantes, o autor produziu uma versão xenófoba do processo de colonização, na qual os fatos históricos não têm grande importância21. A "história" que relata pretende mostrar um avanço deliberado sobre o território sulino - o polvo germânico lançando seus tentáculos a partir de São Leopoldo. E conclui:

“Conforme podemos observar, a colonização germânica criou raízes profundas, desenvolveu-se por todo o sul do Brasil e tomaria aspectos aterradores se não fossem as oportunas medidas adotadas, visando defender os interes- 
ses sagrados da Pátria e desmanchando toda e qualquer possibilidade de desagregação do nosso território" (Nogueira 1947:18).

Na breve avaliação que faz da colonização alemã no Brasil, particularmente no Vale do Itajaí, os nazistas não são os únicos classificados como "demagogos germânicos, solertes e perspicazes" (Nogueira 1947:27), responsáveis pela ausência de brasilidade. A mesma classificação também identifica os primeiros colonizadores, especialmente os que participaram da fundação de colônias, e isso pode ser observado no capítulo dedicado a Hermann Blumenau.

Em primeiro lugar, condena a razão da vinda de Blumenau ao Brasil em 1846, como representante de uma associação alemã, encarregado de observar as condições de vida dos imigrantes, ocasião em que se interessou pela implantação de uma colônia. Para Nogueira, a escolha do Vale do Itajaí estaria relacionada às possibilidades de manter os alemães separados dos nacionais, e aponta a proibição da posse de escravos pelos colonos como indicador mais importante dessa intenção isolacionista, porque "os alemães, sistematicamente, não toleram os negros e daí o cuidado do filósofo germânico em impedir a entrada dos mesmos nas terras da colônia [...]" (Nogueira 1947:56).

Nogueira reporta-se a um documento datado de março de 1848, dirigido à Assembléia Legislativa Provincial, no qual Hermann Blumenau solicita, pela primeira vez, uma concessão de terras destinada à colonização do médio Vale do Itajaí-açu com imigrantes alemães. A solicitação foi rejeitada pela Assembléia. N esse documento existe um artigo que impede a entrada de escravos na colônia; um outro artigo, também mencionado por Nogueira, expressa o compromisso de fazer sair da colônia indivíduos de "índole rixosa" e "notória imoralidade" que ameaçam a moralidade dos colonos. Ambos os artigos são motivados por dispositivos da própria política imigratória brasileira (discutida, inclusive, na M emória do Visconde de A brantes publicada em Berlim, em 1846) - já que a colonização baseada na pequena propriedade familiar era considerada incompatível com o regime escravista. Blumenau estava apenas cumprindo exigências que eram estipuladas pelo governo brasileiro, num momento em que havia interesse explícito na imigração alemã, considerada mais apropriada para produzir os colonos desejáveis.

A primeira proposta de Blumenau era, na verdade, um projeto de lei (daí ter sido enviado à Assembléia Legislativa). A cabou obtendo a concessão por compra, efetuada através da constituição de uma sociedade particular de colonização, formada com um sócio teuto-brasileiro, Fer- 
nando Hackradt - compra autorizada pelo presidente da Província de Santa Catarina. As 150 mil jeiras compradas pela companhia foram, então, demarcadas em lotes coloniais para venda às famílias de imigrantes 22 .

A pós a fundação da colônia, em 1850, Blumenau publicou livretos de propaganda para atrair imigrantes alemães - fato que N ogueira também considera uma prova das tendências de enquistamento próprias das "colônias alemãs". As inúmeras dificuldades enfrentadas no início da colonização levaram a empresa de Blumenau e Hackradt à falência: entre outras coisas, o empreendimento foi prejudicado pela insuficiência de imigrantes - dez anos após a fundação, a colônia tinha apenas 170 famílias assentadas (menos de mil habitantes, em sua maioria alemães evangélico-luteranos). Para manter o empreendimento, o governo imperial assumiu a colônia em 1860 através de um convênio e Blumenau foi mantido como diretor, agora na condição de funcionário assalariado do Estado. Nogueira classificou esse fato (a nomeação de Blumenau) como "grotesco e original" (Nogueira 1947:59)23, atribuindo-Ihe um interesse específico por compatriotas, com a pretensão de "nuclear e isolar o seu pessoal, constituindo um elemento à parte, estranho no ambiente nacional, como em realidade se tornou" (Nogueira 1947:61).

A exemplo de Silvio Romero (1906) - que desqualificou a imigração alemã no Brasil a partir da imagem da invasão germânica do Império Romano (invasão de bárbaros, portanto) - Nogueira usa a imagem da ocupação dos espaços mais férteis do território sulista por estrangeiros sem intenção de incorporar-se à nova pátria, objetivando a segregação desde o início do processo colonizador. N esse contexto, o fundador da primeira colônia alemã do Vale do Itajaí aparece como um oportunista que pretendeu criar "uma N ova A lemanha em terras catarinenses, aproveitando tão esplêndida e fertilíssima gleba", situado, por suas "intenções", no mesmo plano dos propagandistas do III Reich - ainda que lhe sejam rendidas homenagens pela "grandiosa obra realizada" (Nogueira 1947:65-66).

A aparente contradição que, em princípio, pode ser constatada em observações como essa, na verdade, é produto da visão que o autor tem do progresso material (presente, também, no livro de Bethlem): os nacionalizadores admiram o resultado econômico da colonização e condenam as diferenças culturais e sociais que alimentam a valorização simbólica da identidade teuto-brasileira - que incluem a "infiltração" nazista denunciada pelos órgãos policiais. Mas isso não significa que o nazismo seja o objeto privilegiado nos textos aqui analisados. A atuação nazista é 
visualizada mais como elemento de reforço, de aglutinação étnica, do "enquistamento" que sempre existiu. Daí a forma negativa de avaliar a atuação de Blumenau e seu propósito de fundar uma colônia em Santa Catarina - um pecado contra a brasilidade que, afiança Nogueira, nem a natureza tolerou: "Também a natureza lançaria o seu protesto contra a horda col onizadora: o Itajaí aumentando o volume das suas águas, invadiu tudo e provocou, com a enchente, enormes prejuízos nas roças e nas edificações, chegando a perecer afogados vários colonos" (Nogueira 1947:59).

Assim, as cheias periódicas do rio Itajaí-açu, e também os indígenas que atacaram colonos nos primeiros anos da colonização, surgem, simbolicamente, como representantes da xenofobia nacional, reagindo contra o alienígena invasor.

À parte essa maneira peculiar de escrever sobre a história da ocupação do Vale do Itajaí, a descrição que Nogueira faz das diversas localidades da região e, principalmente, da cidade de Blumenau, no início da década de 40, não muda os termos do discurso nacionalista. O território - a base física do jus soli - não devia conter senão uma cultura e uma língua nacional (produtos da formação histórica, de caldeamento, do país), e a campanha de nacionalização impõe-se como único procedimento eficaz para inoculação de sentimentos de brasilidade, transformando alemães e outros estranhos, imbuídos de idéias erradas sobre sua pátria, em brasileiros de fato (e não, apenas, de direito). Weber (1992) já enfatizava a importância do sentimento (de pertencimento) nas representações sobre a comunidade nacional e a comunidade étnica, usando a noção de vida em comum, de habitus. "Sentimento" (nacional) é expressão comum no texto de Nogueira - algo de básico para a formação de um ideal de brasilidade e única condição da formação do verdadeiro brasileiro.

O que descreve na maior parte do livro é uma sociedade que reputa como diferente, estranha, esquisita, que não reconhece como parte do Estado-nação. Hábitos, costumes, língua e religião estranhos, homens e mulheres esquisitos - o “desconhecido", “inimaginável” no território nacional - causando constrangimento e perplexidade aos legítimos representantes da nacionalidade.

O registro das primeiras impressões sobre a cidade de Blumenau recebeu no livro um subtítulo significativo - "Uma Cidade Esquisita", porque a língua alemã é falada "sem constrangimentos", inclusive nas repartições públicas. $\mathrm{Na}$ "viagem ao desconhecido", o primeiro impacto é causado pelo uso de uma língua estrangeira e pela constatação dos nomes germânicos das casas comerciais: "Estávamos cansados de tantos 
nomes estrangeiros. Ficamos absortos, inicialmente, em mil pensamentos. A nós, parecia incrível que pudéssemos penetrar numa cidade, dentro do nosso próprio território, onde nos sentíssemos contrafeitos" (Nogueira 1947:87).

O mesmo tipo de sentimento de estranheza é causado pelas demais cidades "alemãs" da região e, sobretudo, pelos costumes e hábitos descritos como" exóticos". No entanto, N ogueira não se limita a condenar os aspectos mais estritamente contrários à idéia de nação contidos nos pressupostos da campanha. Trata-se, também, de um julgamento moral no confronto de costumes de duas sociedades diferentes. Existem observações sobre a presença nazista (principalmente quando acusa a classe dominante local - os industriais e comerciantes - de ter simpatias pelo III Reich), sobre a ausência de caldeamento racial (o que remete ao mito da formação brasileira), e sobre a substituição da língua portuguesa pela alemã na vida cotidiana. O autor faz o elogio da nacionalização do ensino - que entre 1937 e 1939 erradicou as mais de cem escolas alemãs da região, expulsando os "professores nocivos" aos sentimentos patrióticos - e, sobretudo, mostra desconforto com os "costumes estranhos", porque não consegue identificar ali uma família adequadamente brasileira, nem um catolicismo brasileiro. A vida associativa e o lazer em geral são condenados pelo que considera "excesso de liberalidade", como por exemplo:

“As associações pias não têm a amplitude que se vê em todo o Brasil, o que denota uma certa frieza religiosa do povo.

Poucos são os casamentos católicos. [...] não constituindo fato digno de repulsa da sociedade a união sob contrato de caráter particular. Isto sucede entre pessoas da elite social que, muitas vezes, abandonando a esposa legítima, unem-se a outra mulher, que passa a ser acolhida daí por diante como nova esposa [...]" (Nogueira 1947:48).

“N ão constitui motivo de censura o fato de moças e rapazes freqüentarem sozinhos essas festas ${ }^{24}$ e poucas vezes o caval heiro faz a gentileza de pagar a entrada da sua dama. Do mesmo modo, não são necessárias apresentações protocolares, nem permissões do esposo para que sua senhora conceda uma contradança a qualquer cidadão. As nossas músicas não são ouvidas [... ] a valsa vienense tem a supremacia indiscutível" (Nogueira 1947:81-82).

Os trechos transcritos revelam algumas diferenças costumeiras relacionadas a práticas matrimoniais e religiosas e a hábitos de lazer pouco 
condizentes com o comportamento e a etiqueta social adequados a uma certa moralidade que o autor expressa ao longo do seu relato. As mulheres blumenauenses são criticadas por sua presença em lugares públicos consumindo cerveja e outras bebidas alcoólicas, fazendo ginástica e participando de atividades esportivas nos clubes junto com os homens etc. Esse modo de falar das atividades recreativas femininas, especial mente aquelas desenvolvidas nas associações que sofreram intervenção do Exército (caso das sociedades de ginástica e tiro), é mais do que simples expressão de crítica de comportamento envolvendo estilos de vida. As associações são consideradas locais perigosos, onde a prática esportiva e o lazer servem como aglutinadores para doutrinas alienígenas. Nogueira, como Bethlem, acentuou o caráter étnico dessas associações, informando que "as vistas dos dirigentes da campanha nacionalizadora se voltaram logo para tais centros" (Nogueira 1947:101) - transformados, em toda a região, nos locais de acantonamento para a tropa.

Outros traços culturais que não são relacionados diretamente à questão étnica, mas apontam para diferenças, são arrolados como "exóticos", esquisitices européias mantidas no Brasil pelos descendentes de imigrantes - alguns até motivo de elogios, como os cuidados com a casa e o jardim, a "mesa farta" (hábitos alimentares "baseados em princípios nutritivos"), o lugar de relevo das hortas e pomares, a beleza arquitetônica dos prédios públicos. Alguns "costumes" que chamaram a atenção de Nogueira, demarcadores de diferenças culturais, são inusitados num texto de problemática nacionalista. Além do registro da intensidade da vida associativa, assinala entre outras coisas: "não existe quintal sem patos" (a ave do al moço dominical); gaiolas com canários estão presentes até nos hospitais; terrenos urbanos demarcados por cercas vivas ou grades de madeira "que dão feição interessante" aos jardins; grande quantidade de casas de madeira introduzidas no sul pelos imigrantes; belos palacetes "em estilo europeu"; poucos ônibus e grande quantidade de bicicletas (para as quais existem estacionamentos) circulam nas cidades, além das carroças puxadas por dois cavalos - usadas, inclusive, para ir às festas; nas festas natalinas "o velho amigo da petizada - o Papai N oel - tem outro nome, chama-se Nicolau"; número reduzido de servos, mesmo nas casas dos ricos (até mesmo "as mulheres mais finas" fazem serviços domésticos) etc.

O capítulo III - onde estão arroladas as observações acima (que remetem a um estilo de vida diverso) - engloba uma listagem de traços culturais que operacionalizam as diferenças num sentido étnico, acrescida de detalhes da formação urbana e dos comportamentos reputados como "antibrasileiros" nas cidades visitadas (indiferença pelas datas 
nacionais, uso da língua alemã, por exemplo). A falta de sentimentos de brasilidade, os indícios cotidianos da desnacionalização, segundo seus termos, são assinalados em pequenos episódios - às vezes remetendo à presença nazista. Um exemplo desse tipo de narrativa tem como título "A prenda a falar o alemão" : visitando uma pessoa da família num hospital de Blumenau, o militar não consegue obter informações com a enfermeira que só se expressava em alemão; mostrando-se indignado com a situação, o militar é instado a aprender a língua alemã ou não teria condições de se comunicar na cidade.

A questão da língua volta num outro episódio - intitulado “ Um convite estravagante" - ocorrido numa farmácia onde o proprietário recebe um convite de casamento redigido em alemão. $O$ nome do noivo, impresso no convite, revela sua condição de brasileiro. Nogueira não toma o fato do casamento interétnico como representativo das possibilidades de caldeamento, sempre presente no discurso nacionalista. Para ele, o idioma usado no convite era, antes, indicativo da contaminação que a cultura alemã exercera sobre os nacionais naquela região. E conclui: "não se tratava, em realidade, de simples colonos [...]" (Nogueira 1947:83) - numa clara sugestão de intenções conquistadoras da colonização alemã. N esse episódio é presumida a influência do germanismo a partir de um simples convite de casamento; em outra narrativa, o desvio "do verdadeiro caminho da nacionalidade" é atribuído à atividade nazista. Descreve a prisão de um professor teuto-brasileiro - pelo que se depreende da narrativa, alguém que dava aulas em língua alemã quando já estava em vigência a nacionalização do ensino, e por isso "devia ajustar contas perante a justiça". A prisão é assinalada como ato necessário para libertar as crianças "do pernicioso preceptor que, dia a dia, infiltrava-Ihes no espírito o mais tremendo dos venenos" (N ogueira 1947:72). A menção ao veneno - termo que também é usado por Bethlem - insinua a pregação nazista do professor, embora sua prisão fosse vinculada à proibição do ensino em língua estrangeira.

No entanto, o problema da nacionalização, para Nogueira, é muito mais do que fechar escolas, prender professores "nocivos" e inculcar noções de civismo e de brasilidade através da ação educativa em grêmios, escotismo, serviço militar; enfim, não bastava pôr um ponto final em "monstruosidades" como a escola alemã (cf. Nogueira 1947:119). Nacionalizar significava, principalmente, transformar usos e costumes, mudar uma tradição cultural e social a partir da observação sociológica, "adotando meios coercitivos sobre os que tramarem contra os interesses nacionais", educando a juventude (Nogueira 1947:133). Não utiliza a 
palavra assimilação na avaliação sociológica introduzida no último capítulo (onde cita Gilberto Freyre); mas o modo como entende a nacionalização supõe a assimilação progressiva dos alemães do Vale do Itajaí, conduzida através da ação direta de um Estado forte e centralizador, levada a cabo pelos militares. Assimilação, ou melhor, caldeamento obrigatório, supondo a "erradicação", inclusive, dos costumes "exóticos" (porque, embora toleráveis, não são nacionais).

\section{A hora da reconstrução nacional}

O trabalho de J amundá (1968) traça um perfil nacionalista de Nereu Ramos ${ }^{25}$, ressaltando sua atuação como interventor do Estado Novo em Santa Catarina - especialmente a imposição de uma legislação que atingiu a organização comunitária teuto-brasileira. É um texto laudatório, que destaca Nereu Ramos como legislador rigoroso e idealista, um líder que agia "no interesse da unidade nacional" e que atingiu, com seus decretos, o núcleo da vida comunitária teuto-brasileira, sem levar em conta que o maior contingente de eleitores estava nas áreas dos descendentes dos germânicos (cf. J amundá 1968:43). Esse é o ponto onde J amundá vai além dos problemas específicos da nacionalização. Como Bethlem e Nogueira, defende a campanha em nome da unidade nacional - o país não podia conter brasileiros divorciados da realidade cultural e social da nação. As medidas nacionalizadoras que defende são as mesmas. A opinião que tem sobre a nacionalização do ensino coincide com a de seus colegas militares: "Foi executada através de uma técnica de rompimento do processo de formação de minorias étnicas" (J amundá 1968:20).

O rompimento, portanto, era uma questão de educação do povo e não apenas de substituição das escolas estrangeiras. Nereu Ramos, segundo interpreta J amundá, era tão nacionalista que não mediu sequer as conseqüências das medidas tomadas sobre a população que formava $o$ maior conjunto eleitoral do estado. As querelas políticas estão apenas insinuadas no texto, mas revelam que a campanha de nacionalização não foi, propriamente, uma unanimidade. Os adversários do interventor teuto-brasileiros ou não - se posicionaram contra a intervenção na vida cotidiana, criticando a violência exacerbada e as prisões arbitrárias motivadas pelo uso da língua alemã. Ao atribuir ao interventor os excessos policiais cometidos no curso da campanha, seus adversários fizeram uso político da violência, simbólica ou não, exercida sobre uma população que tivera seus direitos de cidadania diminuídos. "O slogan grosseiro foi 
que era 'inimigo de alemão'. Todavia, os nascidos no Brasil não eram alemães para Nereu Ramos, nem para nenhum de nós" (J amundá 1968:43).

Duas questões estão contidas nessas referências aos inimigos políticos de Nereu Ramos. Em primeiro lugar, as críticas que abrangem os procedimentos da campanha provavelmente surgiram após 1945. Durante o Estado N ovo, o poder pertencia ao interventor nomeado e, na política local, aos prefeitos nomeados - inexistindo Poder Legislativo. J amundá remete aos decretos baixados por Ramos - que atingiram as associações, as escolas particulares, ou que proibiram o uso de nomes estrangeiros em escolas, ruas, sedes municipais etc. Esse fato permitiu aos adversários políticos da oligarquia Ramos (entre os quais estavam os Konder-Bornhausen, a oligarquia teuto-brasileira de Itajaí) responsabilizar Nereu Ramos pela violência nacionalizadora. Durante a campanha, entre as estratégias de Nereu Ramos para acabar com o predomínio político da elite blumenauense, J amundá (1968:70-71) cita o desmembramento do município de Blumenau, forçando a competição com novas lideranças.

Em segundo lugar, aparece a clivagem étnica demarcada pela identidade teuto-brasileira, e a importância política das zonas de colonização germânica, postas sob suspeita pelos princípios que nortearam a campanha. A pesar do pressuposto do jus soli contido no trecho citado, ele possui significado ambíguo: os nacionalistas não consideram alemães os nascidos no Brasil, mas também não os classificam como brasileiros. $E$ às instituições comunitárias étnicas, aos usos e aos costumes é atribuído um caráter nacional. Na visão de J amundá, as medidas legais decorreram de uma necessidade maior - a de interromper a desnacionalização, porque as instituições atingidas eram inspiradas no nacionalismo alemão.

“Pois meus Senhores, eu vi os quatro Ff que a ginasta alemã usou para simbolizar a finalidade patriótica de formação de um jovem sadio naquele sécuIo XIX, porém sabem onde? Nas sociedades de ginástica brasileiras existentes nas pequenas comunidades da área cultural onde os descendentes de alemães dominavam. - Sabem em que ano? - 1939" (J amundá 1968:45)²6.

As primeiras sociedades de ginástica surgiram no contexto de construção simbólica do nacionalismo alemão, no início do século XIX. J amundá, inclusive, reporta a Fichte e Arndt, principais mentores do nacionalismo romântico, para aludir aos projetos de unificação alemã. Nas regiões de colonização alemã, foram mantidas como representativas da cultura alemã, juntamente com as sociedades de tiro - adquirindo caráter de símbolo étnico. Por essa razão, tornaram-se alvos prioritários 
dos mentores da campanha: "Agir contra a existência das associações cívico-culturais foi um imperativo de ordem nacional e adequado àqueles dias tumultuosos [...]" (J amundá 1968:46).

A introdução do termo "cívico" é esclarecedora: as associações eram vistas como locais de formação da mentalidade alemã, como ameaçadoras da apregoada unidade nacional brasileira. Daí a definição de Nereu Ramos como "apenas e inteiriço um nacional izador responsável", cumprindo seu dever de patriota, através da instituição de um aparato legal para combater "a política de germanização e italianidade [...]" (J amundá 1968:50).

A legalidade da campanha, portanto, é destacada para legitimar, inclusive, a violência, sob o argumento da segurança da pátria. A reconstrução nacional, no Estado Novo, dependia do sucesso da assimilação "obra de conquista e catequese" que teve início no momento adequado, quando "o assunto minorias étnicas envolvia nosso país" em razão da presença nazista, aqui e no exterior, em busca de Lebensraum (J amundá 1968:15).

O expurgo das escolas e associações "suspeitas", bem como todas as demais medidas de exceção, utilizando constrangimentos físico e moral, com uso da força, é para J amundá uma ação fundamentada na lei. Entretanto, de modo diverso de Bethlem e Nogueira - que pensaram a campanha como guerra - , reconhece (mas não condena) que na prática cotidiana ocorreram arbitrariedades.

“A minha persistência referente à parte educativa da Campanha de Nacionalização conduziu-me a uma situação especial dentro do grupo. Tornei-me intolerante e, acintosamente, contrário às medidas de ordem policial. Achava que se usava, exorbitantemente, a polícia de repressão. [...] Notei que outros também pensavam assim, todavia não chegavam a falar al to o que pensavam" (J amundá 1968:32).

A pesar desse depoimento, o autor não informa quais medidas de repressão estava condenando. A o longo do texto fala de "atitudes policiais" ou de "abuso de autoridade" - que atribui ao despreparo dos agentes ou às dificuldades de comunicação lingüística (boa parte da população do Vale do Itajaí, por exemplo, não falava o português, e a maioria quase absoluta dos nacionalizadores não conhecia a língua alemã).

O tipo de violência que afetou a população pode ser percebida quando assevera que os colonos não foram prejudicados nas suas atividades produtivas pela proibição do uso dos seus idiomas de origem (alemão, 
italiano e outros). Se houve ou não prejuízo material, esse é um aspecto secundário do problema (e de mensuração impossível) - mas existem registros de prisão ou de coação moral motivados pelo uso de língua estrangeira. Os colonos, em sua maioria, não sabiam se expressar em português e a proibição legal teve efeitos sobre suas vidas cotidianas, dificultando a livre comunicação. O próprio J amundá, em outro momento, diz que a "alegação [dos efeitos negativos da campanha na produção rural] não é totalmente desprovida de fundamento", porém apareceu "nos resíduos de resistência ao processo nacionalizador" 27. E insiste: “o não utilizar a língua vernácula, era como ainda é, uma inconveniência significativa contra a Unidade Patriótica. Efetivamente, não interessa à Unidade Nacional que aquela área produtora de bons índices de riqueza não tenha comunicação com ela" (J amundá 1968:79-80) ${ }^{28}$.

A premissa aí contida remete à língua como princípio fundamental da nacionalidade. E dela resulta a importância atribuída à questão escolar - o sucesso da nacionalização atrelado ao processo de transformação ou erradicação da "escola estrangeira". Os temas da unidade territorial e do cal deamento são secundários na sua argumentação - a questão crucial é a uniformidade lingüística.

Não é por outra razão que J amundá construiu um perfil laudatório de Nereu Ramos calcado, principalmente, nos decretos que facilitaram a intervenção nas escolas e nas associações recreativas e culturais - redutos públicos de transmissão da língua e da cultura dos descendentes de imigrantes. Tratava-se de impedir a formação de minorias nacionais através de uma campanha conduzida por meios legais, respaldada numa razão maior - a segurança nacional.

A utilização do termo minoria29, por outro lado, insinua o problema do nazismo - acionado quando procura justificar as medidas de repressão. O nazismo é o inimigo genérico a ser enfrentado, influência deletéria sobre os descendentes de alemães - e a transformação destes em brasileiros passava pela "desnazificação" - , embora reconheça "que nem todo alemão ou descendente concordava com a nazificação" (J amundá 1968:34). Concretamente, a ameaça nazista é acionada para desculpar a violência das medidas nacionalizadoras, em nome das necessidades da assimilação de brasileiros que se encaminhavam para a formação de minorias por incúria dos políticos da República Velha. A referência aos políticos, nesse caso, é bem precisa (embora J amundá fale genericamente, sem citar nomes): são adversários de Nereu Ramos - com base eleitoral em regiões de colonização alemã e italiana - que se manifestaram contrários à campanha, condenando os métodos mais violentos, especial- 
mente os excessos cometidos contra os que não falavam português. Provavelmente possuíam identidades "hifenadas" - traduzindo etnicidade e cidadania - incompatíveis com os princípios assimilacionistas que determinaram os rumos da ação ${ }^{30}$.

A meta era incorporar os descendentes dos imigrantes no melting pot nacional. Isto, nos termos de J amundá, jamais seria obtido pela força. Era preciso primeiro conhecer esses brasileiros desnacionalizados, entendê-los.

“Foi, justamente, ao ler o cientista social Emílio Willems, por recomendação de Nereu Ramos, que me ilustrei. Daí para diante os meus pecados diminuíram na freqüência com que aconteciam, passei a enxergar o problema da nacionalização procurando controlar a emocionalidade.

E entendi, que estava no M elting Pot onde o descendente do imigrante alemão entrado em 1850 estava querendo demorar em ser brasileiro, quando pelo nascimento já o era" (J amundá 1968:32-33).

N esse caso, um estudo acadêmico sobre a assimilação dos alemães (Willems 1940), no qual também existem informações sobre diversos aspectos do pertencimento étnico germânico, serviu como orientação ao oficial do Exército, no sentido de pensar a nacionalização, principalmente, como um processo educativo. A menção aos conflitos internos do grupo nacionalista mostram que a desejada moderação da "atuação agressiva" realmente não aconteceu.

\section{Considerações finais}

A o mencionar a influência do estudo de Emílio Willems sobre seu modo de ver a colonização alemã, J amundá não estava sendo um nacionalizador mais moderado. Quis apenas dizer que tal obra permitiu um melhor entendimento da resistência teuto-brasileira à campanha e, por extensão, ao melting pot (portanto, à assimilação). Isso significa que percebeu a importância da idéia de pertencimento étnico à nação alemã (as demais etnias são apenas mencionadas, ocasionalmente, no livro) - uma das marcas da identidade teuto-brasileira -, mas como forma indevida de nacionalismo estrangeiro introduzido e consolidado ao longo do fluxo imigratório. A formação da nação exigia a incorporação dos imigrantes através de um processo de assimilação, também chamado de caldeamento, por suas implicações de mistura racial: a campanha foi uma tentativa 
de assimilação forçada, que o discurso militar, aqui analisado a partir das representações de três oficiais do Exército dela participantes, classificou como imperativo da unidade nacional.

A citação do trabalho de Willems (1940) tem outras implicações. Indica a influência das teorias acadêmicas sobre assimilação, em voga nas ciências sociais nas décadas de 30/40, fundamentadas, em grande parte, nos estudos sobre imigração nos Estados Unidos, onde também emergiu, no início do século XX, a idéia popular de melting pot. Em ambas as teorias existe a suposição de que as diferenças culturais e sociais das populações imigradas são superáveis, permitindo a incorporação gradual à nova sociedade a partir da segunda geração. A autoconsciência nacional dos imigrantes, embora mantida pela primeira geração, limitando a assi milação, seria gradualmente perdida nas gerações subseqüentes. Essa perspectiva reflete ideais integracionistas em relação à imigração européia nos Estados Unidos - e melting pot, na forma popularizada, implicava uma imagem de incorporação dos europeus à vida americana portanto, sua "americanização" 31 .

O sentido do "abrasileiramento" pretendido pelos integrantes da campanha é, praticamente, o mesmo - a incorporação à sociedade brasileira -, mas numa concepção bem ampla de melting pot, supondo também a integração racial pelo "caldeamento". A aposta nacionalizadora se fez, então, sobre as gerações mais jovens, nascidas no Brasil - como se pode depreender dos textos analisados, que enfatizam, repetidamente, a necessidade de erradicação das "escolas estrangeiras". A nacionalização do ensino é o tema preponderante nos trabalhos de Bethlem e J amundá, e a assimilação como problema educativo aparece nos três textos, através da condenação do uso de idiomas estrangeiros e da apologia do escotismo, do serviço militar e da prática do civismo.

A assimilação (e seu sinônimo naquele contexto da campanha - caldeamento) é entendida como nacionalização, e não simplesmente como processo de mudança cultural e social: tratava-se de transformar indivíduos nascidos no Brasil - portanto, brasileiros segundo o jus soli - em "nacionais". Nesse caso, a incorporação dos desnacionalizados implicava a mudança das mentalidades e dos significados simbólicos atrelados a nacionalismos estranhos.

A assimilação como questão nacional tem como premissa a substituição dos símbolos étnicos por outros representativos da brasilidade. Daí a insistência na imposição de práticas cívicas e no desmonte da estrutura comunitária étnica representada pelas escolas, associações e pelo uso das línguas maternas. M uito mais do que as diferenças concretas - sociais e 
culturais - os nacionalizadores pretendiam atingir as ideologias étnicas, os sentimentos de etnicidade. Não é por outra razão que Bethlem queria a cabeça do padre polonês, que J amundá elogiou os decretos que modificaram as denominações de ruas, clubes e localidades, e que N ogueira sugeriu a troca das lápides nos cemitérios; e todos insistiram na "virulência" da doutrinação nazista - pelo que representava em termos de cristalização de um nacionalismo racial —, embora nenhum deles limitasse o alcance das medidas repressivas aos descendentes de alemães.

O exemplo mais expressivo de substituição simbólica está no trabaIho de Nogueira, no capítulo dedicado a uma interpretação sobre as intenções de Hermann Blumenau. Ao perfil negativo do colonizador, contrapõe uma fala repleta de elogios ao guia brasileiro que conduziu o alemão nas viagens de reconhecimento ao rio Itajaí-açu, antes da fundação da colônia. Ressalta o heroísmo do caboclo injustiçado, que não recebeu reconhecimento algum por seu trabalho de desbravamento porque a cidade de Blumenau só rende homenagens e ergue estátuas para os teutos. E afirma: "o nome do dr. Blumenau deve ser substituído pelo de Ângelo Dias, o intimerato caboclo catarinense" (Nogueira 1947:64). Aí está uma clara sugestão de troca do nome da cidade, onde a figura simbólica do caldeamento deve substituir a figura simbólica do enquistamento. A final, Blumenau fundou sua colônia na "seara tropical do caldeamento", segundo imagem de retórica do general M eira Vasconcellos evocada por Bethlem (1939:176).

O Exército entrou na campanha para impor o nacionalismo através da educação cívica e do cerceamento formal das etnicidades. A ação foi interpretada como obra de conquista: levar o espírito de brasilidade a uma parte do território ocupada por colonizadores alienígenas. Na visão dos que planejaram a ação, no sul, o Exército emerge como guardião das virtudes cívicas da nação, e a campanha como instrumento legítimo do Estado para chegar à unidade nacional. O princípio da nacionalidade (cf. H obsbawm 1991), nessa perspectiva militar, exigia a equação Estadonação-povo, e a assimilação dos alienígenas, seu caldeamento, era essencial para a formação do povo. 
Giralda Seyferth é professora do Programa de Pós-Graduação em Antropologia Social (PPGAS) do Museu Nacional/UFRJ ; mestre pela mesma instituição e doutora em Ciências Humanas (Antropologia Social) pela Universidade de São Paulo.

\section{Notas}

1 Tais críticas não se restringem à política imigratória; de um modo geral, os ideólogos do Estado Novo imaginaram uma Primeira República distanciada dos ideais de construção nacional e sem compromisso com a unidade da nação. Ver, Oliveira, Velloso e Gomes (1982).

2 O uso desse termo é significativo porque transforma os grupos étnicos em elementos patológicos, supondo a necessidade de remoção.

3 Cf. Romero (1906; 1949). O equilíbrio populacional pretendido remete à tese sobre o branqueamento da população brasileira defendida pelo autor.

4 A campanha de nacionalização tem sido ignorada pela historiografia local. Alguns abusos cometidos em nome do patriotismo no Vale do Itajaí, por exemplo, são citados por J amundá (1968).

5 Dez anos após a fundação da colônia Blumenau, o governo provincial promoveu o assentamento de alemães no Itajaí-mirim; ao mesmo tempo, Blumenau foi o ponto de partida para o povoamento de todo o Vale do Itajaí-açu — por iniciativa oficial ou pela concessão de terras a companhias de colonização, como a Sociedade Colonizadora Hanseática, que deviam lotear as áreas recebidas e vendê-las aos colonos na forma da lei.

6 A pesar dessa aparente heterogeneidade, a maioria da população tem origem alemã e italiana. Franceses e irlandeses não suportaram as condições de assentamento na colônia do Itajaí-mirim e se retiraram, após alguns conflitos com a administração, na década de 1870 . Os russos dos registros oficiais eram, na verdade, teuto-russos falantes da língua alemã, caso, também, de uma parte dos poloneses e húngaros. Os imigrantes das outras nacionalidades têm peso estatístico insignificante e os que permaneceram na região se germanizaram.

7 Sobre os pressupostos raciais que nortearam e dificultaram o acesso de brasileiros ao sistema de colonização, ver Seyferth (1991; 1996). 
8 Desde 1824, são poucos os períodos em que a entrada de imigrantes alemães no Brasil ultrapassou os 2 mil indivíduos anuais. Aumentos substantivos neste número só ocorreram em dois momentos: antes da Primeira Guerra M undial e no início da década de 20 (em 1924, por exemplo, são registrados mais de 20 mil indivíduos) (cf. Carneiro 1950). No discurso nacionalista, a associação desse aumento da imigração nos anos 20 com o nazismo foi inevitável!

9 O maior número de escolas estrangeiras estava nas áreas de colonização alemã; eram aproximadamente 1.500, por volta de 1937, só no Rio Grande do Sul (cf. Kreut 1994).

10 Sobre essa questão, ver Diniz (1983).

11 O perfil doutrinário do Estado N ovo é analisado em Oliveira, Velloso e Gomes (1982).

${ }_{12}$ Angela de Castro Gomes mostra que houve uma releitura do movimento imigratório na qual os nordestinos, que começaram a migrar para São Paulo e Rio de J aneiro na década de 20, assumiram a condição de novos bandeirantes que retomariam o Brasil para os nacionais (cf. Oliveira, Velloso e Gomes 1982:161).

$13 \mathrm{O}$ discurso de Blumenau foi transcrito em Vargas (1940: vol. VII), e nele é ressaltada a função educadora e nacionalizadora do Exército nacional.

${ }^{14}$ Conforme conceitos de Anderson (1983) e Hobsbawm (1991).

${ }^{15}$ As motivações de natureza antiétnica, da mesma forma, estão presentes nos textos de Nogueira e J amundá. Este último, no início do primeiro capítulo, informa que o general Meira de Vasconcellos ficou alarmado com a naturalidade com que muitos brasileiros cultuavam outra história, outra nacionalidade e falavam outra língua, ensinada em "escolas estrangeiras" - vindo daí a motivação para planejar a intervenção militar (cf. J amundá 1968:12).

16 “É de $60 \%$ o número dos que não falam e nem mesmo compreendem a nossa língua; de $30 \%$ os que, embora compreendendo e falando, procuram não falar e não se consideram brasileiros; de $10 \%$, unicamente, os que identificados à nossa nacionalidade, falam nossa língua e amam nossa pátria" (Bethlem 1939:32, ênfases minhas). Não há menção sobre as fontes desses percentuais, e o sentido de exclusão nacional está, de certa forma, implícito no uso do pronome.

17 Ver, por exemplo, as observações sobre "caboclização" dos imigrantes em Willems (1940; 1946) e Martins (1955).

${ }^{18} \mathrm{~A}$ expressão foi usada para comentar a dificuldade de superar as idéias alienígenas junto à população de J oinville (SC): "Seus cérebros envenenados, não aceitavam a pujança indiscutível de nossas doutrinas e intimamente se tornavam mais traidores ainda" (Bethlem 1939:139). 
19 As manifestações nacionalistas sobre o "perigo alemão", no contexto da expansão imperialista do II Reich, são analisadas em Seyferth (1994).

20 O uso exemplar da guerra civil espanhola provavelmente está associado à pregação anti-socialista, presente quando o autor defende a centralização política promovida pelo Estado Novo.

21 Os equívocos cometidos por Nogueira são muitos, mas não tem sentido confrontá-los com a historiografia da imigração alemã. Para ficar apenas com a questão da terra, a única explicação para o uso do termo latifúndio é a possibilidade do autor estar se referindo às áreas totais das colônias (o que não parece ser o caso) quase sempre terras devolutas - sem levar em conta o tamanho de cada lote. Em 1824, a concessão familiar tinha cerca de 75 hectares, tamanho que, progressivamente, foi diminuindo ao longo do século XIX até chegar ao padrão de 25 hectares.

22 Sobre os problemas que cercaram a fundação da colônia de Blumenau, ver o livro de Silva (s/d).

23 O convênio estipulou um preço pela transferência da colônia ao Estado a companhia de colonização havia comprado a concessão em 1850 e investiu em benfeitorias e imóveis na sede da colônia; descontadas as dívidas, Blumenau recebeu 30 contos pelas 20 léguas quadradas e benfeitorias (cf. Silva s/d:70). Além da nomeação para a diretoria da colônia, esse pagamento deve ser a razão da censura de Nogueira ao governo imperial.

$24 \mathrm{O}$ autor mostra-se espantado com a quantidade de associações e salões de baile encontrados por toda parte - censurando o "exagero" da vida associativa com sua algazarra e multiplicidade de jogos e bailes. As festas mencionadas no texto são os bailes realizados nos finais de semana nos inúmeros salões existentes na cidade e no meio rural.

25 Nereu Ramos (1888-1958) nasceu em Lajes (SC) e surgiu na cena política em 1911 como deputado estadual. Participou da Revolução de 1930 como um dos líderes da Aliança Liberal. Foi deputado constituinte em 1934, governador eleito pela Assembléia Legislativa em 1935, e interventor nomeado de 1937 a 1945. Depois de 1945 exerceu o cargo de vice-presidente da República, foi deputado e senador em várias legislaturas. A pesar do título do livro, é destacado apenas o papel de Nereu Ramos como principal figura da campanha de nacionalização em Santa Catarina.

26 As sociedades de ginástica (Turnvereine) foram inspiradas na organização das Turnherrschaften, idealizadas por F.L. J ahn, no início do século XIX. As Turnherrschaften, além da prática da ginástica, tinham a finalidade de treinar patriotas - já que o contexto histórico era o do domínio napoleônico. Tinham, pois, um caráter nacionalista. Os quatro efes mencionados por J amundá fazem parte da bandeira da associação, referindo-se às palavras Frisch (lépido), Fromm (devotado), Froelich (alegre) e Frei (livre). 
27 Há algumas indicações de conflitos provocados, às vezes, por ameaças infundadas, atribuídas a "aproveitadores" e "incompetentes" que tentaram usar a campanha em proveito próprio - como no caso de uma proprietária de indústria, em Blumenau, que procurou as autoridades alarmada com a possibilidade de intervenção na sua fábrica (cf. J amundá 1968:35).

28 O tempo verbal no presente, incluído na frase, mostra a insatisfação do autor com os resultados da campanha. Afinal, em 1968, línguas estrangeiras ainda podiam ser ouvidas em Santa Catarina.

29 O termo minoria é usado por J amundá denotando possibilidades separatistas, no sentido de que representa um pertencimento nacional incompatível com a idéia de Estado-nação.

30 Deve ser lembrado que, durante a República Velha, o poder político foi exercido por pessoas ligadas ao Vale do Itajaí (como Hercílio Luz e os irmãos Konder) e por teuto-brasileiros como Lauro Müller e Felipe Schmidt. O mandato de governador, concluído em 1930, foi exercido por Adolfo Konder; após a Revolução de 1930, a cena política foi dominada pela família Ramos.

31 Assimilação e americanização são processos sociais definidos para a imigração européia - portanto, branca. Park (1935) aponta para obstáculos de natureza racial que dificultam a integração dos asiáticos e negros na sociedade americana, impedindo, segundo ele, a utilização do conceito de assimilação para estudar as "relações raciais". No verbete "Americanization", da Enciclopaedia of the Social Sciences (1935) é dado destaque à adaptação rápida dos europeus.

\section{Referências bibliográficas}

ANDERSON, Benedict. 1983. Imagined Communities. Reflections on the Origin and Spread of Nationalism. London: Verso.

BETHLEM, Hugo. 1939. O Vale do Itajaí. J ornadas de Civismo. Rio de J aneiro: J osé Olympio.

CARNEIRO, J . Fernando. 1950. I migração e Colonização no Brasil. Rio de J aneiro: FNF, Cadeira de Geografia do Brasil, Publicação Avulsa, № 2.
COELHO, Edmundo Campos. 1976. Em Busca de Identidade. O Exército e a Política na Sociedade Brasileira. Rio de J aneiro: Forense Universitária.

DINIZ, Eli. 1983. “O Estado Novo: Estrutura de Poder. Relações de Classe". In: B. Fausto (org.), História Geral da Civilização Brasileira. Tomo III (3). São Paulo: Difel. pp. 77-120.

EPSTEIN, A.L. 1978. Ethos and Identity. London: Tavistock. 
HOBSBAWM, Eric J . 1991. Nações e Nacionalismo desde 1780 . Rio de J aneiro: Paz e Terra.

JAMUNDÁ, Theobaldo Costa. 1968. Nereu Ramos. O da Hora da Reconstrução Nacional. Florianópolis: Edição do Autor.

KREUTZ, Lucio. 1994. “A Escola TeutoBrasileira Católica e a Nacionalização do Ensino". In: T. L. Müller (org.), N acional ização e I migração Alemã. São Leopoldo: Editora Unisinos. pp. 27-64.

MARTINS, Wilson. 1955. Um Brasil Diferente. São Paulo: Anhembi.

MAUSS, M arcel. 1969. “La N ation”. In: Oeuvres (vol. 3.). Paris: M inuit. pp. 573-639.

NOGUEIRA, Rui Alencar. 1947. Nacionalização do Vale do I tajaí. Rio de J aneiro: Ministério do Exército.

OLIVEIRA, Lucia L., VELLOSO, M onica P. e GOMES, Angela de Castro. 1982. Estado N ovo: I deologia e Poder. Rio de J aneiro: Zahar.

PARK, Robert E. 1935. "Assimilation, Social". Enciclopaedia of the Social Sciences (vol. II). New York: M acmilIan. pp. 281-283.

PARSONS, Talcott. 1975. "Some Theoretical Considerations on the Nature and Trends of Change of Ethnicity". In: N. Glaser e P. D. Moynihan (orgs.), Ethnicity: Theory and Experience. Cambridge, Mass.: Harvard University Press. pp. 53-83.

ROMERO, Silvio. 1906. O Allemanismo no Sul do Brasil. Rio de Janeiro: Heitor Ribeiro.

. 1949. História da Literatura Brasileira (4a ed). Rio de J aneiro: J osé Olympio.

SEYFERTH, Giralda. 1991. “Os Paradoxos da Miscigenação". Estudos Afro-Asiáticos, 20:165-186.

.1994. "O Incidente do Panther (Itajaí, SC, 1905): Estudo sobre Ide- ologias Étnicas". A ntropologia Social. Comunicações do PPGAS, 4: 15-80.

. 1996. “Construindo a Nação: Hierarquias Raciais e o Papel do Racismo na Política de Migração e Colonização". In: M. C. Maio e R. V. Santos (orgs.), Raça, Ciência e Sociedade. Rio de J aneiro: Editora Fiocruz, Centro Cultural Banco do Brasil. pp. 41-58.

SILVA, J osé Ferreira da. s/d. História de Blumenau. Florianópolis: Edeme.

VARGAS, Getúlio. 1940. A N ova Política do Brasil (vol. VII). Rio de J aneiro: J osé Olympio.

WEBER, Max. 1992. Economia e Sociedade. Brasília: Editora da Universidade de Brasília.

WILLEMS, Emílio. 1940. Assimilação e Populações Marginais no Brasil. São Paulo: Cia. Editora Nacional. . 1946. A culturação dos Alemães no Brasil. São Paulo: Cia. Editora Nacional. 
Resumo

A campanha de nacionalização instituída durante o Estado Novo (1937-1945) interferiu na vida cotidiana dos imigrantes e descendentes estabelecidos no Brasil - denominados alienígenas em razão das etnicidades prevalecentes e das culturas diferenciadas - exigindo sua assimilação (enquanto sinônimo de caldeamento) em nome da unidade nacional. O presente artigo focaliza aspectos do discurso militar sobre a campanha e seus objetivos de assimilação forçada, a partir de textos produzidos por oficiais do Exército que trabalharam como agentes da nacionalização no Vale do Itajaí (SC) - região considerada paradigma de "enquistamento", afastada dos princípios da "brasilidade". Procura mostrar que, na condução da campanha pelos militares, prevaleceu uma concepção de Estado-nação que negou legitimidade a quaisquer formas de pertencimento étnico, conforme parâmetros próprios da ideologia nacionalista brasileira gestada desde o século XIX.

\section{Abstract}

The nationalization campaign promoted during the Estado Novo (1937-1945) interfered in the daily lives of immigrants and their descendents in Brazil - labeled as aliens because of the prevailing ethnicities and the differentiated cultures - requiring their assimilation (as a synonym for miscegenation) in the name of national unity. This study focuses on aspects of the military discourse related to this campaign and its objectives of forced assimilation, based on documents produced by Army officers working as agents for nationalization in the Itajaí Valley, in the State of Santa Catarina, a region viewed as a paradigm of "encystment", straying from the principles of "Brazilianness". It seeks to demonstrate how - in the campaign by the military - a concept of nation-state prevailed which denied legitimacy to any form of ethnic belonging, in accordance with the very parameters of Brazilian nationalist ideology as fomented since the 19th century. 